\title{
Phased oscillations in cell numbers and nitrate in batch cultures of Alexandrium tamarense (Dinophyceae)
}

\author{
Yves Collos ${ }^{1,{ }^{*}}$, Imene Hadjadji ${ }^{1}$, Benoit Plisson ${ }^{1}$, Philippe Cecchi ${ }^{1}$, Mohamed Laabir ${ }^{1}$, \\ Christian Bechemin ${ }^{2}$, Estelle Masseret ${ }^{3}$
}

\footnotetext{
${ }^{1}$ Université Montpellier 2, Ecologie des Systèmes Marins Côtiers, UMR 5119 CNRS, IRD, CC093, 34095 Montpellier Cedex 5, France

2 Ifremer, Laboratoire Environnement Ressources des Pertuis Charentais, BP 7 - 17137 L'Houmeau, France

3 Université Montpellier 2, Ecologie des Systèmes Marins Côtiers, UMR 5119 CNRS, IRD, CC093, 34095 Montpellier Cedex 5, France
}

*: Corresponding author : Yves Collos, email address : Yves.Collos@univ-montp2.fr

\begin{abstract}
:
Alexandrium tamarense (M. Lebour) Balech strains isolated in spring 2007 from a single bloom in Thau lagoon have been grown in nonaxenic artificial media. For three strains showing large oscillations in biomass (crashes followed by recoveries) on a scale of several days, a significant relationship was observed between changes in cell densities (as in vivo fluorescence) and changes in nitrate concentrations. Increases in cell densities were accompanied by decreases in nitrate, while decreases in cell densities corresponded to increases in nitrate, presumably due to nitrification. Net increases in nitrate could reach up to $15 \mu \mathrm{mol} \mathrm{N} \cdot \mathrm{L}^{-1} \cdot \mathrm{d}^{-1}$ indicating a very active nitrifying archaeal/bacterial population. However, following population crashes, algal cells can recover and attain biomass levels similar to those reached during the first growth phase. This finding indicates that those archaea/bacteria do not compete for nutrients or do not hamper algal growth under those conditions. In contrast to diatoms, dinoflagellates such as $A$. tamarense do not excrete/exude dissolved organic matter, thus preventing excessive bacterial growth. This mechanism could help explain the recovery of this species in the presence of bacteria.
\end{abstract}

Keywords : Alexandrium tamarense ; archaea ; bacteria ; decay ; Growth ; Nitrate ; Nitrification ; oscillations
Abbreviations :
DOC dissolved organic carbon
DON dissolved organic nitrogen
IVF in vivo fluorescence
TN total nitrogen 


\section{Introduction}

Oscillations in phytoplankton biomass are known to occur over the daily time scale either in bulk measurements of chlorophyll a (Glooschenko et al. 1972, Collos et al. 1989) or in terms of cell numbers (Nelson and Brand 1979, Siu et al. 1997) and are also sometimes related to parallel changes in dissolved organic carbon (Burney et al. 1982) or dissolved inorganic nitrogen (Collos et al. 1992). Such patterns indicate intense exchanges of material between the particulate and the dissolved phase on the hourly time scale. On a longer time scale (days), decreases in microalgal biomass can be related to net increases in nitrate (Jacques et al. 1976, Collos et al. 1988) that indicate nitrification of organic compounds resulting from cell degradation. During batch growth of Alexandrium catenella/tamarense, a large variability in growth curves was observed (Collos et al. 2006), with stationary phases sometimes followed by renewed growth or not, as well as population crashes, sometimes also followed by recovery or not. The recovery of such algae in non axenic medium was particularly surprising as bacteria are expected to take over in such situations for phytoplankton in general (Smayda 1996, Doucette et al. 1999, Uribe and Espejo 2003) and A. tamarense in particular (Su et al. 2007, Wang et al. 2007, 2010). Bacteria are also thought to terminate dinoflagellate blooms in situ (Smayda 1996 and references therein). In order to better understand the dynamics of such behavior, we measured simultaneously algal biomass of $A$. tamarense and nitrate concentrations in the medium during growth, degradation and eventual recovery of cells.

\section{Materials and methods}

Several strains of Alexandrium tamarense were isolated in May 2007 in the Thau lagoon (Crique de l'Angle), southern France. Stock cultures were maintained on ESNW (natural seawater enriched with nutrients at ESAW medium level (Harrison et al. 1980, Andersen et al. 2005) at $20 \pm 1^{\circ} \mathrm{C}$ and $100 \mu \mathrm{mol}$ photons $\cdot \mathrm{m}^{-2} \cdot \mathrm{s}^{-1}$ in a $12: 12$ light:dark cycle. Strains were then transferred to totally artificial seawater ESAW medium (initial nitrate concentration : 549 $\mu \mathrm{M}$ ) and their growth was followed in three replicates for at least 25 days in $200 \mathrm{ml}$ of medium in $250 \mathrm{ml}$ polystyrene vials. Those experiments were done on batch cultures under the same experimental conditions as the stock cultures. Sampling was done every fourth up to every other day in order to minimize detrimental effects of stirring as this species is very sensitive to agitation (Hu et al. 2006). In vivo fluorescence (IVF) was measured on a PerkinElmer (Beaconsfield, Buckinghamshire, UK) LS50B spectrofluorometer (single measurement on each of three replicate cultures) and calibrated against cell counts by Nageotte (Brand $\mathrm{GmbH}$, Wertheim, Germany) hemocytometer. Growth rate was estimated from linear regressions of natural log of IVF values vs. time (Guillard 1973). Points that were not aligned were visually rejected. When several growth phases occurred, i. e. crashes followed by recoveries, only growth rates from the first growth phase were reported. Nitrate was followed by ultraviolet spectrophotometry (Collos et al. 1999) after filtration on $0.2 \mu \mathrm{m}$ Pall Corp. (Ann Arbor, MI, USA) Acrodisc HT Tuffryn membranes. Nitrite was measured following Bendschneider and Robinson (1952).

Twenty strains were examined in total. Eight did not grow on ESAW medium. Among the remaining 12 strains, none showed classical growth curves, but we focused here on those (A7-2, B9-3, H11-2) that showed the most irregular growth curves.

The amounts of dissolved organic carbon (DOC) and total nitrogen (TN) were simultaneously measured in water samples by high temperature catalytic oxidation method using the TOC-V Shimadzu instrument connected in series with the TNM-1 unit from Shimadzu Corporation (Kyoto, Japan). After acidification to eliminate the inorganic carbon, sparge gas is bubbled through the sample to eliminate the inorganic carbon component. Then, the sample is 
injected into the combustion tube which is filled with an oxidation catalyst heated to $680^{\circ} \mathrm{C}$. The sample is burned in the combustion tube. As a result, total nitrogen (TN) decomposes to nitrogen monoxide and the dissolved organic carbon (DOC) of the samples is simultaneously oxidized to form carbon dioxide $\left(\mathrm{CO}_{2}\right)$. Combustion products are conducted by the carrier gas to a dehumidifier and through a halogen scrubber to remove halogens. Finally, combustion products are delivered to the cell of non-dispersive infrared (NDIR) gas analyzer where $\mathrm{CO}_{2}$ is detected and to the chemiluminescence gas analyzer for nitrogen monoxide detection.

Each detection signal generates a peak which can be compared with a standard signal from calibrations curves. Two calibration curves are generated separately using 8 points. One calibration curve is prepared with potassium hydrogen phthalate for the DOC and a second is prepared with potassium nitrate for nitrogen calibration. Analyses for standards or samples are made in triplicates. Dissolved organic nitrogen is obtained by substracting nitrate, nitrite and ammonium from TN values. Filtration on $0.2 \mu \mathrm{m}$ Pall Corp. (Ann Arbor, MI, USA) Acrodisc HT Tuffryn membranes did not contribute any nitrogen (either organic or inorganic) to the medium, but did contribute some organic carbon $(92 \mu \mathrm{M}$ in $10 \mathrm{ml}$ filtrates, with $\mathrm{CV}$ of $5 \%$ from triplicate measurements).

\section{Results}

Changes in cell densities and nitrate concentrations are shown for three strains (Fig. 1, 2 and 3). Growth rates were respectively $0.18,0.13$ and $0.29 \mathrm{~d}^{-1}$ for strain $\mathrm{H} 11-2$, B9-3 and A7-2, with lag phases of 4,6 and 2 days respectively. A. tamarense growth, depicted here as increases in cell numbers, was reflected in decreases in nitrate concentrations. The decreases in cell densities were not always simultaneous in replicate cultures for a particular strain (Fig. 1 and 2), as there was sometimes a 2 day offset in such trends (day 12 and 14 for strain H11-2, Fig. 1). A particularly striking feature was that decreases in cell densities were often paralleled by increase in nitrate concentrations. For example, nitrate could increase by as much as $30 \mu \mathrm{M}$ over the sampling interval during decreases in cell densities of strain B9-3 (days 11-13 in Fig. 2) or strain H11-2 (days 26-28 in Fig. 1).

The same data were then presented as changes in in vivo fluorescence (IVF) between two consecutive samplings as a function of changes in nitrate for the 3 strains (Fig. 4, 5 and 6). In each case there was a significant relationship between both variables. Cell growth is illustrated by increases in IVF (positive values), that are paralleled by net decreases in nitrate (negative values of $\Delta \mathrm{NO}_{3}$ ). Cell degradation is shown by decreases in IVF (negative values), also accompanied by net increases in nitrate (positive values of $\Delta \mathrm{NO}_{3}$ ). Most of the data points lie in the growth/nitrate consumption part, but several points illustrate extensive biomass degradation and net increases in nitrate that can be up to $30 \mu \mathrm{M}$ over the two day sampling interval (Fig. 4 and 5).

The slopes of the regressions shown in Fig. 4, 5 and 6 are similar for strains B9-3 and H11-2, but are different from that of strain A7-2, indicating that the stoichiometry between both processes may differ between strains.

A repeat growth experiment was done with strain B9-3 including nitrite measurements. Nitrite increased regularly from about $0.5 \mu \mathrm{M}$ to about $4.5 \mu \mathrm{M}$ when cell densities reached the first low point, then decreased slightly as cell densities increased again. 


\section{Discussion}

In cases where we observed population crashes, an increase in nitrate was observed simultaneously (Fig. 1 and 2). The precision of the method ( $\pm 1 \mu \mathrm{M})$ used here for nitrate determinations is not as high as the more classical colorimetric method (Wood et al. 1967), but it is high enough to show significant increases in nitrate over two day intervals. This increase could be due to two different reasons. It could either come from internal nitrate that is released upon cell lysis, or from archaeal/bacterial nitrification. For example, in the case of strain B9-3 (days 11-13 in Fig. 2), changes in IVF correspond to a decrease in cell density of about 1200 cells. $\mathrm{mL}^{-1}$, observed over a 2 day period, in parallel to an increase in nitrate of about $29 \mu \mathrm{M}$.

From internal nitrate values published by Thoresen et al. (1982) on this species, a value of about $0.6 \mu \mathrm{M}$ is obtained if this nitrate is directly released in the medium. This value represents only about $2 \%$ of the observed increase in nitrate. Therefore, nitrification is most probably at the origin of such increases $\left(5\right.$ to $\left.10 \mu \mathrm{mol} \cdot \mathrm{L}^{-1} \cdot \mathrm{d}^{-1}\right)$ that have also been observed in the natural environment during incubations (Jacques et al. 1976, Collos et al. 1988, Ward 2008).

From values of $A$. tamarense $\mathrm{N}$ cell content published by Leong and Taguchi (2004), and decreases in cell densities, assuming full transformation of cell $\mathrm{N}$ into nitrate, values of 34 to $53 \mu \mathrm{M}$ for increases in nitrate are estimated over two days. This is sufficient to account for the increase in nitrate of $29 \mu \mathrm{M}$ measured over the same period. This also shows that all cell $\mathrm{N}$ is probably not fully transformed into nitrate during such degradation phases.

The variations in nitrite followed during strain B9-3 growth are difficult to interpret in as much as they could originate from two different processes: ammonium oxidation by nitrifiers, but also nitrite excretion during nitrate assimilation by the alga. Flynn and Flynn (1998) have shown evidence for such a phenomenon in the related species $A$. minutum.

Nitrifiers can be either autotrophs or heterotrophs (Ward 2008). In our case, nitrification occurred only during degradation phases of $A$. tamarense. This species is not known to excrete dissolved organic matter during growth (Chen and Wangersky 1996a), but following stationary phase, cell decline can lead to an increase in dissolved organic carbon (DOC) of about $130 \mu \mathrm{M}$ in the study of Chen and Wangersky (1996a). This would be equivalent to about $20 \mu \mathrm{M}$ dissolved organic nitrogen (DON) when converted to $\mathrm{N}$ by the Redfield ratio. So probably, this input of DON stimulated heterotrophic nitrifiers (no bacterial cell counts are available) and led to the observed increase in nitrate. Such large increases (up to $15 \mu \mathrm{molN}$. $\mathrm{L}^{-1} \cdot \mathrm{d}^{-1}$ ) are in the upper range of nitrification rates in marine environments (Ward 2008). Nitrite did not accumulate and ammonium was not measured here but Collos et al. (1988) did not observe any accumulation of such intermediate compounds during extensive degradation $\left(10 \mu \mathrm{g} \mathrm{Chl} \mathrm{a} \cdot \mathrm{L}^{-1}\right)$ of a natural bloom over a similar time scale.

The parallel changes (increase and decrease) in both phytoplankton cells and nitrate have already been observed in natural populations of phytoplankton dominated by the dinoflagellate Prorocentrum minimum (Collos et al. 1992) and indicate intense exchanges of material between particulate and dissolved phases over the daily time scale. The important nitrification observed during phases of cell degradation implies a large and active archaeal/bacterial population. However, this does not keep the $A$. tamarense population from recovering and going into a second growth phase. At this stage, nitrate is still around 500 $\mu \mathrm{M}$, so nitrogen cannot be limiting. Possibly, DON/DOC becomes limiting for bacteria (Thingstad et al. 2007). In our ESAW medium, DOC was around $250 \mu \mathrm{M}$, similar to that measured in the natural seawater used by Chen and Wangersky $(1996 a, b)$, and DON was near $20 \mu \mathrm{M}$. 
In semi-continuous cultures, Loureiro et al. (2009) showed that $A$. catenella is able to use DON/DOC for growth and keeps those compounds at low levels (DON $<3 \mu \mathrm{M}$ and DOC < $190 \mu \mathrm{M}$ ) during exponential growth. Moreover, bacteria and viruses were also kept at low levels under such conditions $\left(<0.5 \times 10^{6} \cdot \mathrm{mL}^{-1}\right.$ and $<5 \times 10^{6} \cdot \mathrm{mL}^{-1}$ respectively).

For $A$. catenella, Uribe and Espejo (2003) reported no effect of bacteria on growth $(0.2 \pm 0.03$ $\mathrm{d}^{-1}$ for both treatments). The only difference was found at the level of the stationary phase, where bacteria led to a population crash, but the bacteria population did not benefit from the crash (no increase in bacterial cell numbers). In the same study, however, Fig. 1 in Uribe and Espejo (2003) shows that such crashes (from about 1000 to 100 cells. $\mathrm{mL}^{-1}$ in 10 days) could be followed by recovery (from 100 to 1000 cells. $\mathrm{mL}^{-1}$ in 15 days). This is similar in amplitude and time scale to our own results.

For A. minutum, similar or even larger decreases in cell densities (up to 4000 cells. $\mathrm{mL}^{-1}$ over 2 days) were reported by Davidson et al. (1999), but these do not seem to be due to bacteria as the cultures were axenic. Those crashes were not due to $\mathrm{N}$ limitation either because they took place between 2 and 6 days (depending on irradiance) following nitrate exhaustion from the medium. The recoveries, that sometimes led to higher biomass levels than during the first growth phase, took place in absence of nitrate, so $A$. minutum must have relied upon organic nitrogen released from lyzed cells during the previous crash.

Concerning A. tamarense, neither Cole et al. (1975) nor Hold et al. (2001) found an influence of bacteria on its growth rate (called Gonyaulax tamarensis at the time): $0.32 \mathrm{~d}^{-1}$ for axenic conditions vs 0.34 with bacteria in the former study and $0.14 \mathrm{~d}^{-1}$ in the latter. Except at high concentrations of added bacteria, no effect was detected by Zheng et al. (2005) on $A$. tamarense growth. They observed decreases in control cultures of 2000 cells . $\mathrm{mL}^{-1}$ in 2 days immediately followed by increases of 3000 cells . $\mathrm{mL}^{-1}$ in 2 more days near the stationary phase. Again, this is similar or even greater in amplitude and time scale than our own results on the same species. The only way to obtain definitive cell lysis of $A$. tamarense was to add an organic medium to stimulate bacterial growth (Wang et al. 2010).

Among the many causes (autocatalytic effects, microbial infection, nutrient limitation, selfshading) leading to the stationary phase or cell density declines in cultures of phytoplankton (Fogg 1971, Smayda 1996), only the first two seem to be significant here. Still, the reasons behind those population crashes are not clear because autocatalytic effects or microbial infection would have to be reversible in order to explain the observed patterns.

All those different lines of evidence indicate that $A$. tamarense is able to recover in presence of bacteria by keeping a low level of dissolved organic matter in cultures. According to Kamjunke and Tittel (2009), mixotrophic algae recycle organic exudates from near the cell surface and therefore show very low exudation rates that do not lead to bacterial growth. This is consistent with observations by Chen and Wangersky (1996a) who showed that, in contrast to diatoms, dinoflagellates such as $A$. tamarense do not excrete dissolved organic matter. This mechanism could help explain the recovery of this species in the presence of bacteria.

\section{Acknowledgments}

This study was financed by CNRS (Centre National de la Recherche Scientifique) EC2CO program and Ifremer (Institut Français de Recherche pour l'Exploitation de la Mer) ALTOX program. We thank Elise Hatey for help with figures. 


\section{References}

Andersen, R. A., Berges, J. A., Harrison, P. J. \& Watanabe, M. M. 2005. Recipes for freshwater and seawater media. In Andersen, R. A. [Ed.] Algal culturing Techniques. Elsevier, Amsterdam, pp. 429-538.

Bendschneider, K. \& Robinson, R.J. 1952. A new spectrophotometric method for the determination of nitrite in seawater. J. Mar. Res. 11:87-96.

Burney, C. M., Davis, P. G., Johnson, K. M., \& Sieburth, J. McN. 1982. Diel relationships of microbial trophic groups and in situ dissolved carbohydrate dynamics in the Caribbean Sea. Mar. Biol. 67:311-322.

Chen, W. \& Wangersky, P. J. 1996a. Production of dissolved organic carbon in phytoplankton cultures as measured by high-temperature catalytic oxidation and ultraviolet photo-oxidation methods. J. Plankton Res. 18:1201-1211.

Chen, W. \& Wangersky, P. J. 1996b. Rates of microbial degradation of dissolved organic carbon from phytoplankton cultures. J. Plankton Res. 18:521-1533.

Cole, E. J., Yentsch, C. M., Yentsch, C. S. \& Salvaggio, M. 1975. Some of the growth characteristics of Gonyaulax tamarensis isolated from the Gulf of Maine. Environmental Letters 9: 153-166.

Collos, Y., Linley, E. A. S., Frikha, M. G. \& Ravail, B. 1988. Phytoplankton death and nitrification at low temperatures. Est. Coast. Shelf Sci. 27:341-347.

Collos, Y., Maestrini, S. Y. \& Robert, J.-M. 1989. Nocturnal synthesis and diurnal degradation of phytoplankton biomass in surface waters. Mar. Biol. 101:457-462.

Collos, Y., Descolas-Gros, C., Fontugne, M., Mortain-Bertrand, A., Chrétiennot-Dinet, M. J. \& Frikha, M. G. 1992. Carbon and nitrogen dynamics during growth and degradation of phytoplankton under natural surface irradiance. Mar. Biol. 112:491-496.

Collos, Y., Mornet, F., Sciandra, A., Waser, N., Larson, A. \& Harrison, P. J. 1999. An optical method for the rapid measurement of micromolar levels of nitrate in marine phytoplankton cultures. J. Appl. Phycol. 11:189-194.

Collos, Y., Lespilette, M., Vaquer, A., Laabir, M. \& Pastoureaud, A. 2006. Uptake and accumulation of ammonium by Alexandrium catenella during nutrient pulses. Afr. J. Mar. Sci. 28:313-318.

Davidson, K., Wood, G., John, E.H. \& Flynn, K.J. 1999. An investigation of non-steady-state algal growth. I. An experimental model ecosystem. J. Plankton Res. 21:811-837.

Doucette G. J., McGovern, E. R. \& Babinchak, J. A. 1999. Algicidal bacteria active against Gymnodinium breve (Dinophyceae). I. Bacterial isolation and characterization of killing activity. J. Phycol. 35:1447-1454.

Flynn, K.J., Flynn, K. 1998. Release of nitrite by marine dinoflagellates : development of a mathematical simulation. Mar. Biol. 130:455-470. 
Fogg, G.E. 1971. Algal cultures and phytoplankton ecology. $3^{\text {rd }}$ ed. The University of Wisconsin Press, Madison, 269 pp.

Glooschenko, W. A., Curl, H. Jr. \& Small, L. F. 1972. Diel periodicity of chlorophyll a concentrations in Oregon coastal waters. J. Fish. Res. Bd. Canada 29:1253-1259.

Guillard R. R. L. 1973. Division rates. In Stein, J. R. [Ed.] Handbook of phycological methods. Culture methods and growth measurements. Cambridge University Press, London, UK, pp. 289-311.

Harrison, P. J., Waters, R. E. \& Taylor, F. J. R. 1980. A broad spectrum artificial seawater medium for coastal and open ocean phytoplankton. J. Phycol. 16:28-35.

Hold, G. L., Smith, E. A., Birkbeck, T. H. \& Gallacher, S. 2001. Comparison of paralytic shellfish toxin (PST) production by the dinoflagellates Alexandrium lusitanicum NEPCC 253 and Alexandrium tamarense NEPCC 407 in the presence and absence of bacteria. FEMS Microbiology Ecology 36:223-234.

Hu, H., Shi, Y. \& Cong, W. 2006. Improvement in growth and toxin production of Alexandrium tamarense by two-step culture method. J. Appl. Phycol. 18:119-126.

Jacques, G., Fiala, M., Neveux, J. \& Panouse, M. 1976. Fertilisation de communautés phytoplanctoniques. II. Cas d'un milieu eutrophe: upwelling des côtes du Sahara espagnol. J. Exp. Mar. Biol. Ecol. 24:165-175.

Kamjunke, N. \& Tittel, J. 2009. Mixotrophic algae constrain the loss of organic carbon by exudation. J. Phycol. 45:807-811.

Leong, S. C. Y. \& Taguchi, S. 2004. Response of the dinoflagellate Alexandrium tamarense to a range of nitrogen sources and concentrations: growth rate, chemical carbon and nitrogen, and pigments. Hydrobiol. 515:215-224.

Loureiro, S., Garcés, E., Collos, Y., Vaqué, D. \& Camp, J. 2009. Effect of marine autotrophic dissolved organic matter (DOM) on Alexandrium catenella in semi-continuous cultures. $J$. Plankton Res. 31:1363-1372.

Nelson, D. M. \& Brand, L. E. 1979. Cell periodicity in 13 species of marine phytoplankton on a light:dark cycle. J. Phycol. 15:67-75.

Siu, G. K. Y., Young, M. L. C. \& Chan, D. K. O. 1997. Environmental and nutritional factors which regulate population dynamics and toxin production in the dinoflagellate Alexandrium catenella. Hydrobiol. 352:117-140.

Smayda, T. J. 1996. Dinoflagellate bloom cycles: what is the role of cellular growth rate and bacteria ? In Yasumoto, T., Oshima, Y., Fukuyo, Y. [Eds.] Harmful and toxic algal blooms. Intergovernmental Oceanographic Commission of UNESCO, Paris, pp. 331-334.

Thingstad, T. F., Havskum, H., Zweifel, U.L., Berdalet, E., Sala, M. M., Peters, F., Alcaraz, M., Scharek, R., Perez, M., Jacquet, S., Flaten, G. A.F., Dolan, J. R., Marrasé, C., Rassoulzadegan, F., Hagstrøm, A. \& Vaulot, D. 2007. Ability of a "minimum" microbial food web model to reproduce response patterns observed in mesocosms manipulated with $\mathrm{N}$ and P, glucose, and Si. J. Mar. Systems 64:15-34.

Thoresen, S. S., Dortch, Q. \& Ahmed, S. I. 1982. Comparison of methods for extracting intracellular pools of inorganic nitrogen from phytoplankton. J. Plankton Res. 4:695-704. 
Uribe, P. \& Espejo, R. T. 2003. Effect of associated bacteria on the growth and toxicity of Alexandrium catenella. Appl. Env. Microbiol. 69:659-662.

Wang, X., Zhou, L.H., Zheng, T.L. \& Ning, X.R. 2007. Lysis of Alexandrium tamarense mediated by bacteria in its phycosphere. Acta Ecologica Sinica 27:2864-2871.

Wang, X., Li, Z., Su, J., Tian, Y., Ning, X., Hong, H. \& Zheng, T. 2010. Lysis of a red-tide causing alga, Alexandrium tamarense, caused by bacteria from its phycosphere. Biol. Control 52:123-130.

Ward, B.B. 2008. Nitrification in marine systems. In Capone, D.G., Bronk, D.A., Mulholland, M.R., Carpenter, E.J. [Eds.] Nitrogen in the marine environment. Elsevier, Amsterdam, pp. 199-248.

Wood, E. D., Armstrong, F. A. J. \& Richard, F. A. 1967. Determination of nitrate in sea water by cadmium copper-reduction to nitrite. J. Mar. Biol. Assn. U.K. 47:23-31.

Zheng, T.L., Su, J.Q., Maskaoui , K., Yu, Z.M., Hu, J.S. \& Hong, H.S. 2005. Microbial modulation in the biomass and toxin production of a red-tide causing alga. Mar. Poll. Bull. 51: 018-1025.

\section{Figures}

Fig. 1. Growth curves for three replicate cultures of Alexandrium tamarense strain H11-2 as measured by cell numbers converted from in vivo fluorescence (filled symbols) and nitrate concentrations (open symbols).

Fig. 2. Growth curves for three replicate cultures of Alexandrium tamarense strain B9-3 as measured by cell numbers converted from in vivo fluorescence (filled symbols) and nitrate concentrations (open symbols).

Fig. 3. Growth curves for two replicate cultures of Alexandrium tamarense strain A7-2 as measured by cell numbers converted from in vivo fluorescence (filled symbols) and nitrate concentrations (open symbols).

Fig. 4. Changes in in vivo fluorescence (IVF) as a function of changes in nitrate in batch cultures of Alexandrium tamarense strain H11-2. Positive values indicate cell growth or nitrate production. Negative values indicate cell degradation or nitrate consumption.

$Y=-0.42 x-1.9, r^{2}=0.492, n=33, p<0.01$

Fig. 5. Changes in in vivo fluorescence (IVF) as a function of changes in nitrate in batch cultures of Alexandrium tamarense strain B9-3. Positive values indicate cell growth or nitrate production. Negative values indicate cell degradation or nitrate consumption.

$\mathrm{Y}=-0.45 \mathrm{x}-2.5, \mathrm{r}^{2}=0.505, \mathrm{n}=30, \mathrm{p}<0.01$

Fig. 6. Changes in in vivo fluorescence (IVF) as a function of changes in nitrate in batch cultures of Alexandrium tamarense strain A7-2. Positive values indicate cell growth or nitrate production. Negative values indicate cell degradation or nitrate consumption.

$Y=-0.71 x-8.6, r^{2}=0.499, n=20, p<0.01$ 


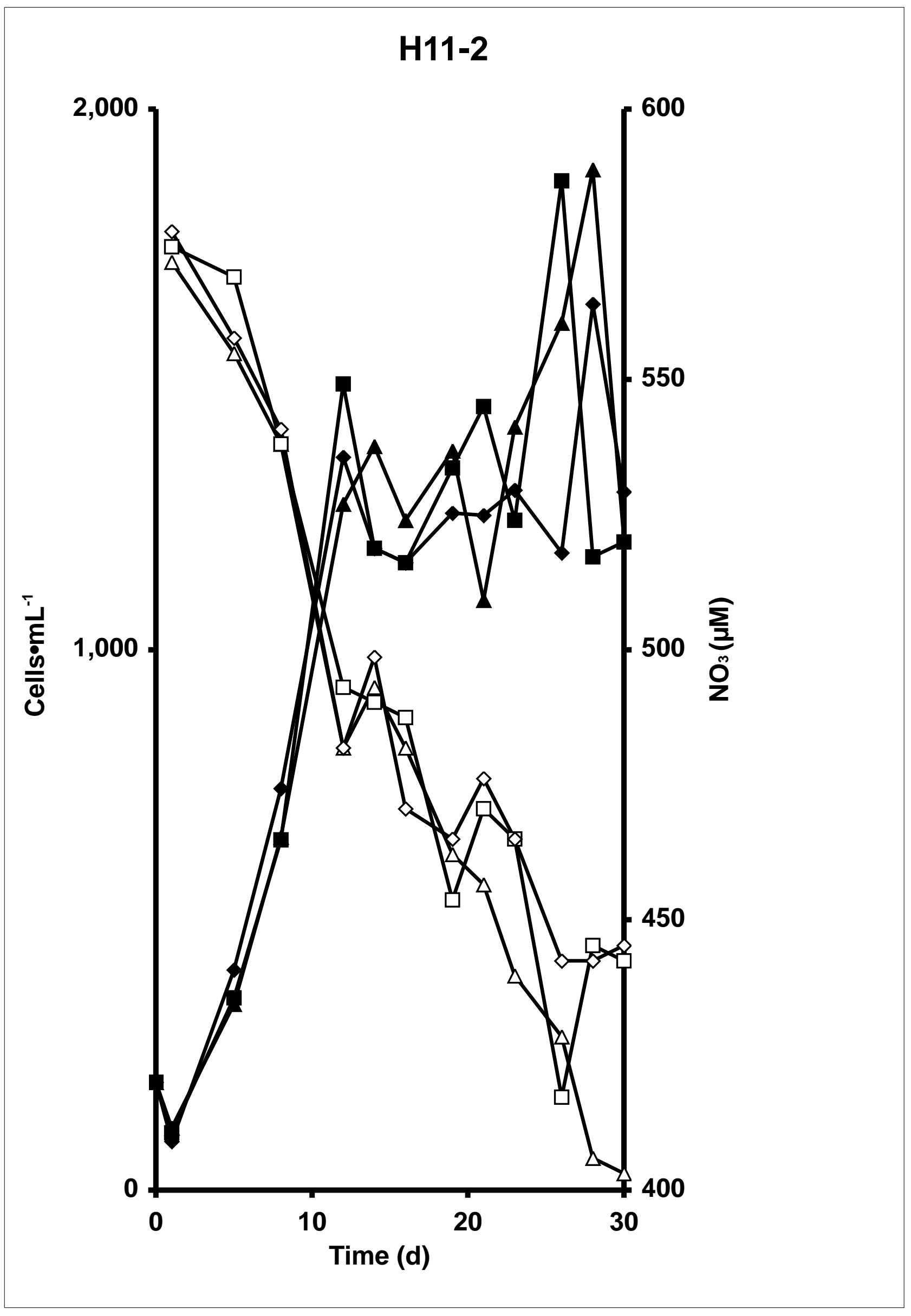




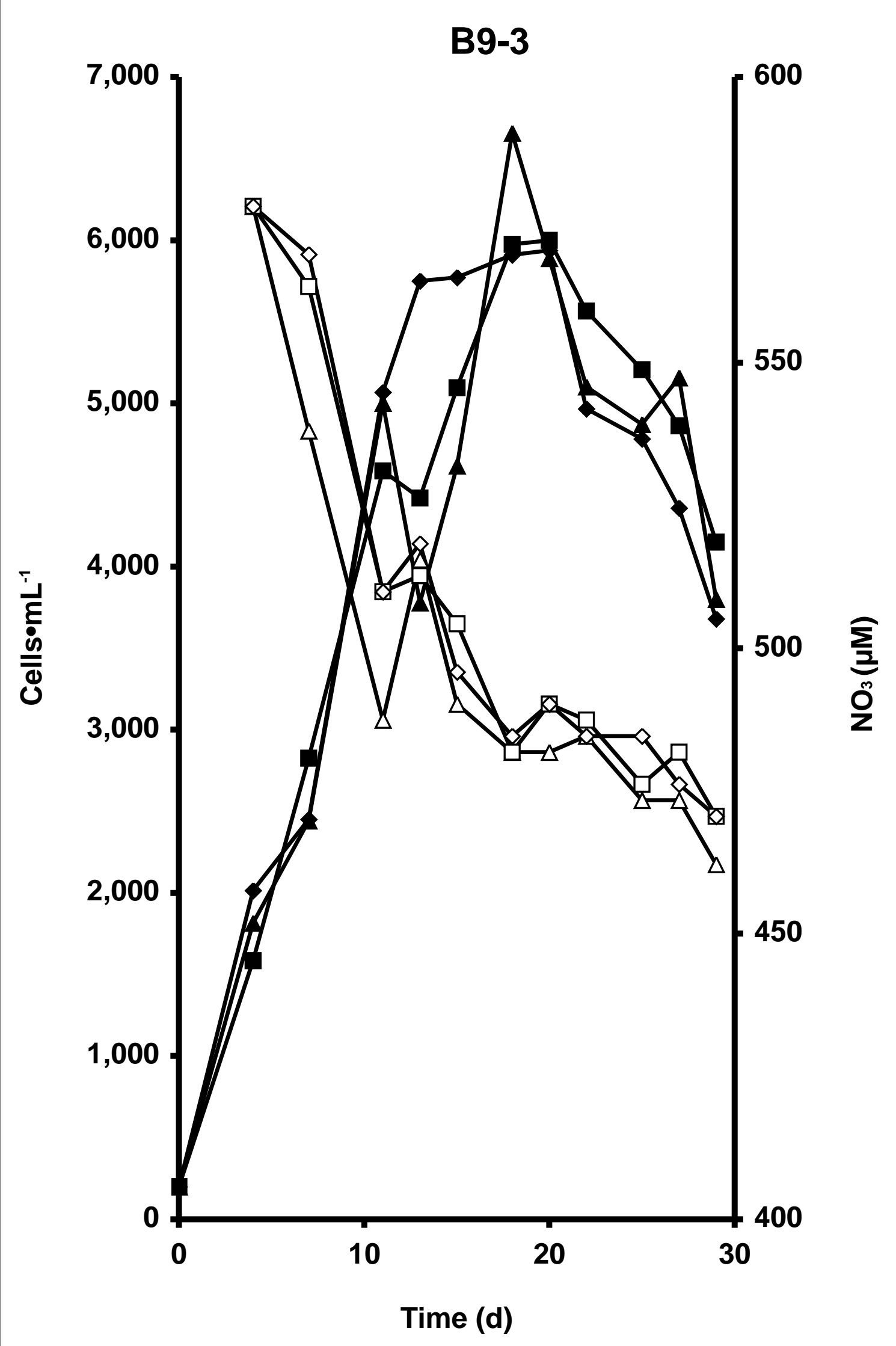




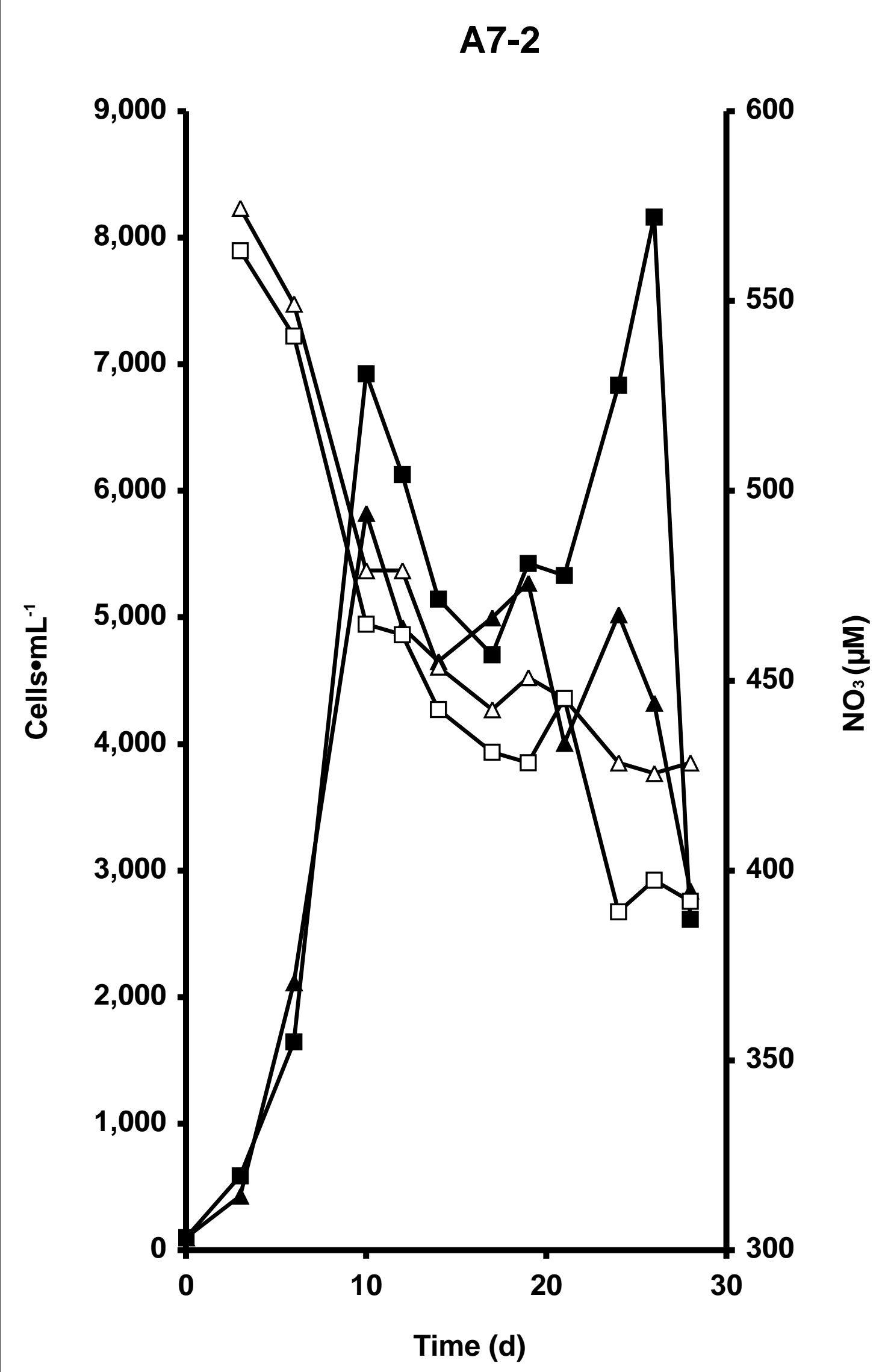




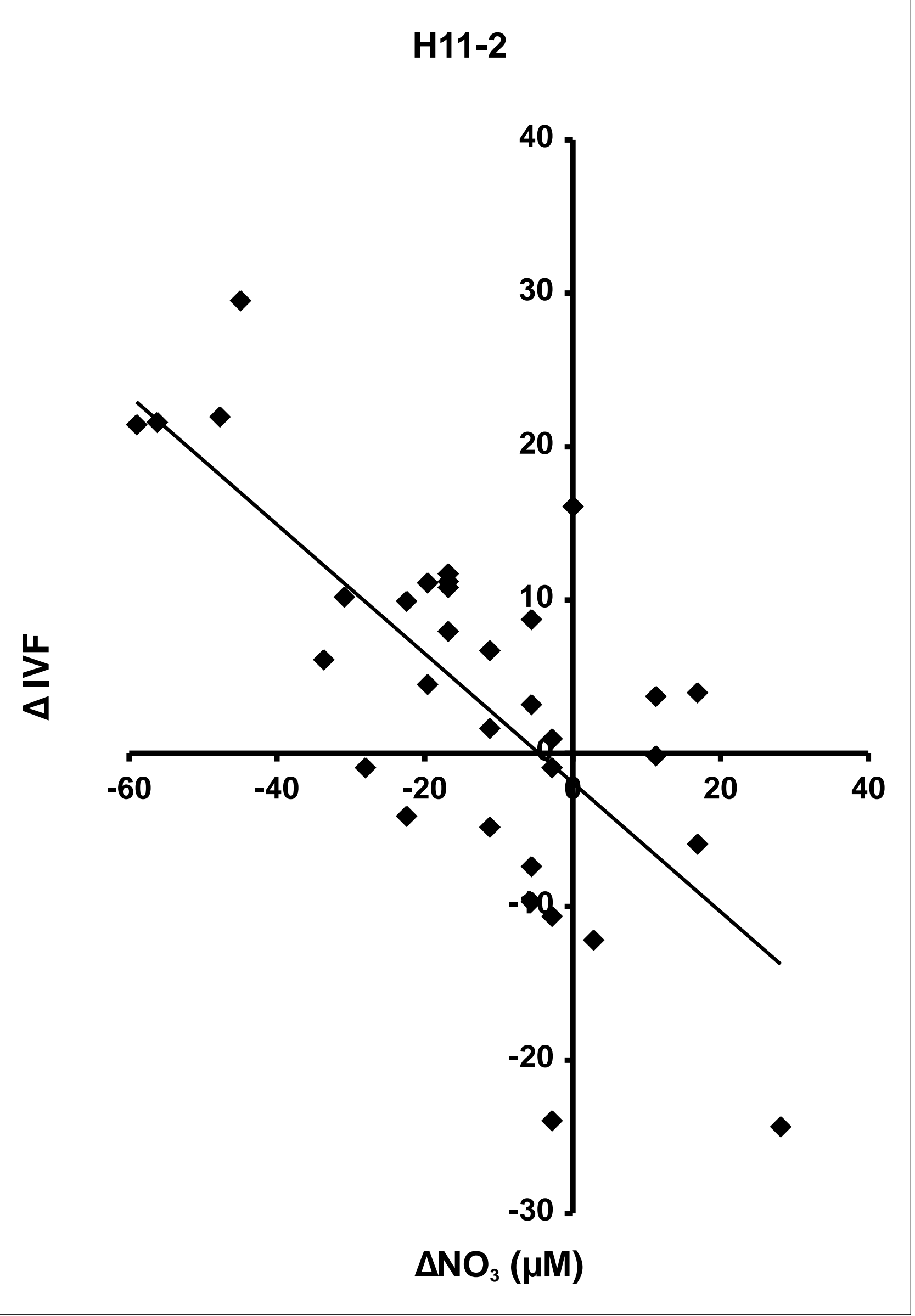




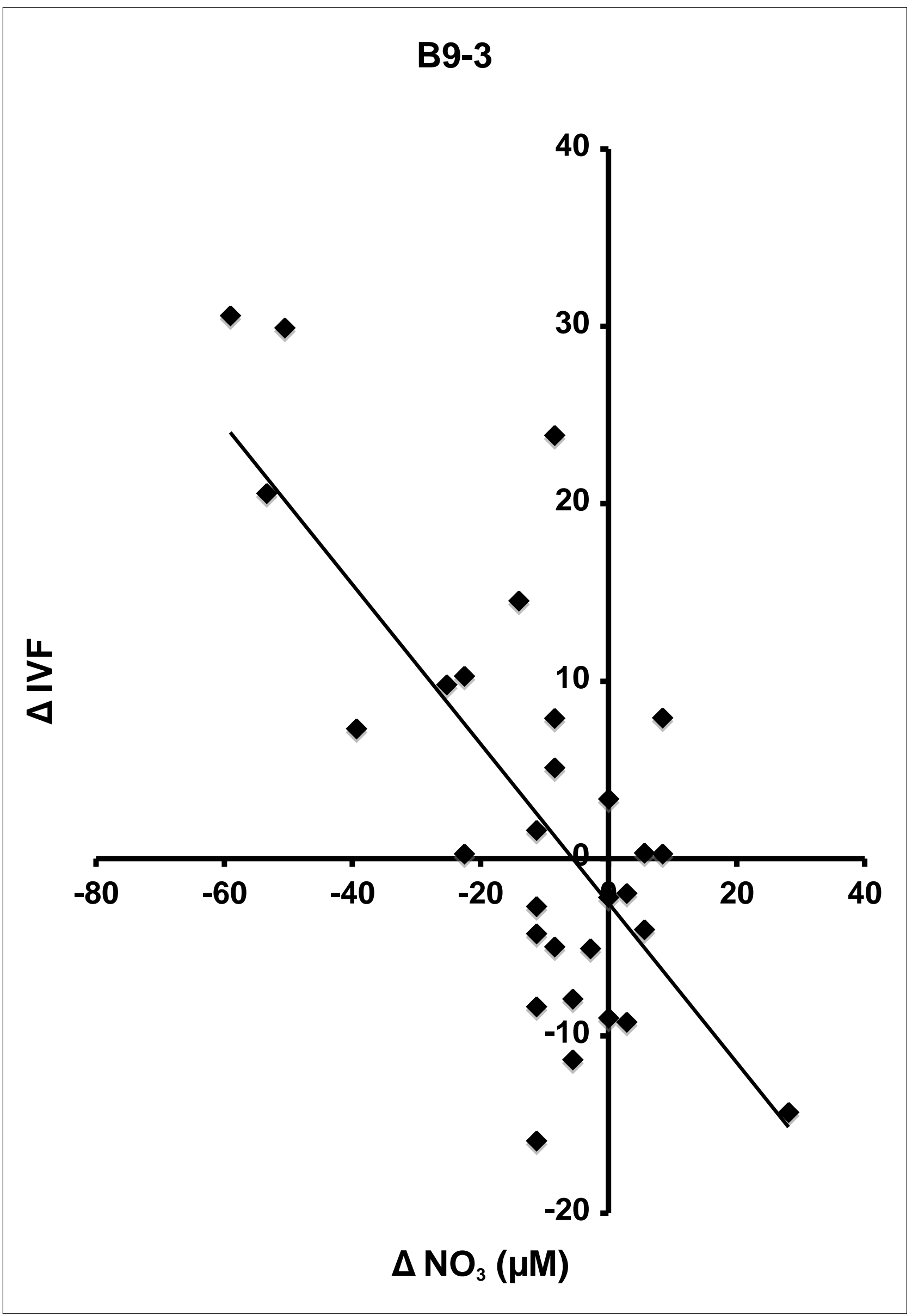




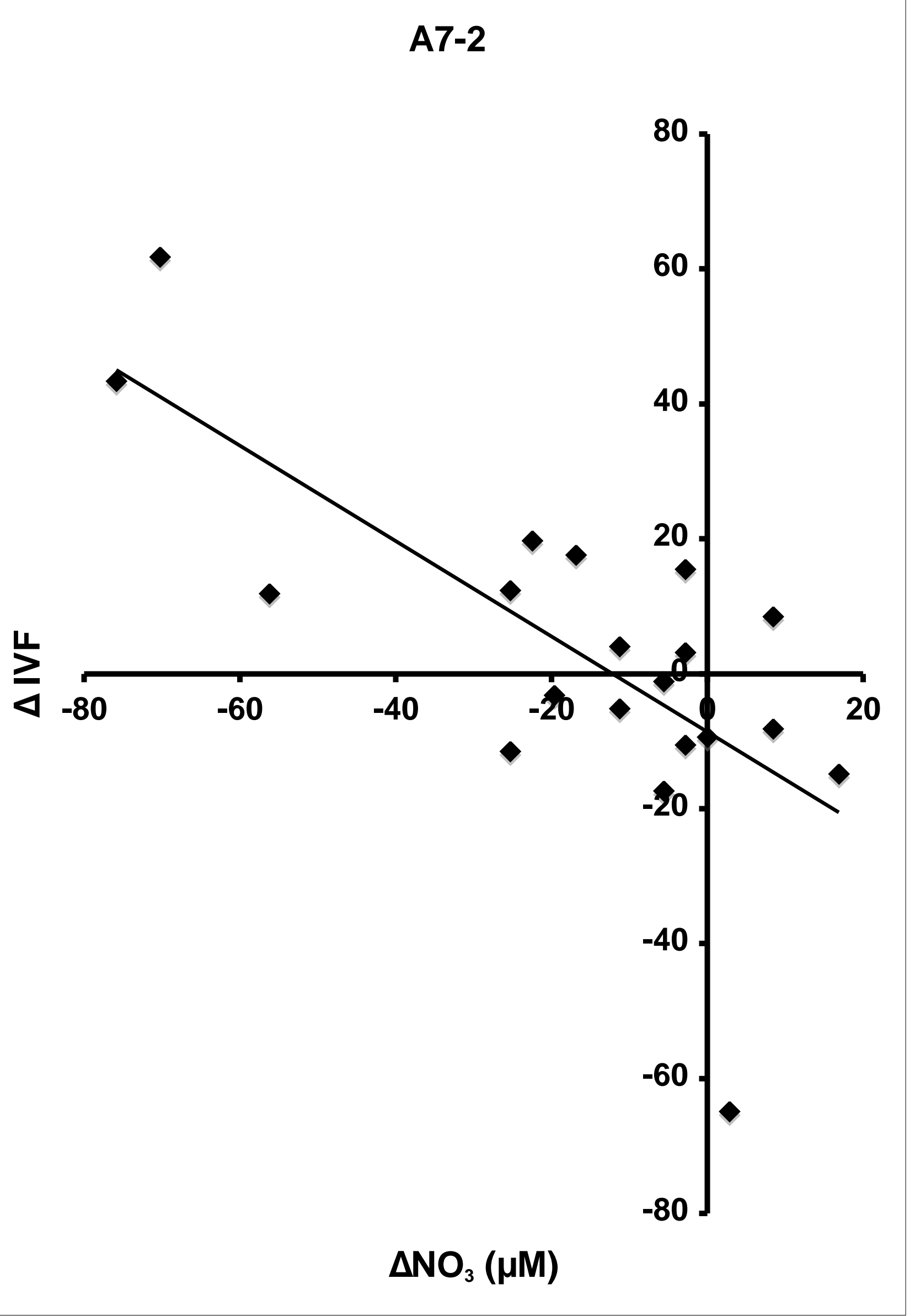

